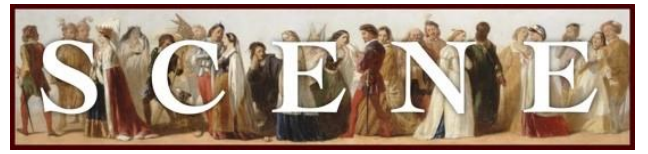

\title{
The Making of a Prince Among The Pogues: Henry IV, Part 1 by Wooden O/Seattle Shakespeare Company
}

by Heather Easterling. Written on 2015-08-30. Published in 2017 Issue 1.

For the production: Henry IV, Part I (2015, Seattle Shakespeare Company, USA).

IT'S BEEN A HOT SUMmeR IN THE PACIFIC NoRThwest, AND THE EVENING OF AUgUst 30 IN Luther Burbank Park on Mercer Island was no different as an audience began to gather on the slopes of the park's natural amphitheater. Such a languid evening -- with picnic-baskets and local co-op containers being unpacked; blankets, low-chairs and bug-spray being spread - was nonetheless charged with anticipation, as programs for Wooden O's Henry IV, Part I emerged from a box and music began to mark the play-space. Wooden $O$ has been presenting free performances of Shakespeare in Seattle's parks for over twenty years (first season was 1993), and on this Thursday evening I got a strong sense of being among many regulars, people who nodded appreciatively and knowingly at the cast member who introduced the show and described ways to donate to and support Wooden $O$. Not a regular, myself, I found this communal atmosphere inviting in the midst of the Seattle metropolis. A lot was in store for us

Henry IV, Part I is a popular and highly comedic Shakespeare play, but is perhaps not obvious summer-fare. Shakespeare's histories tend to be light on the pastoral or romantic elements of such common outdoor offerings as A Midsummer Night's Dream. And so I found myself with a couple of questions as the play began: What would be the possibilities of Wooden O's outdoor spaces for its production of this play? How will this production use the natural setting? My questions were answered by a play that used its grass slopes and wooded park setting to bring out the holiday license of Falstaff, especially the Gadshill caper, as well as the fraught political negotiations and combat of acts 4 and 5, both staged in vividly topographic terms with swift movement up and downhill. The spare outdoor stage, set with four brown and white wall panels and a large table, was transformed regularly and effectively into throne-room, tavern, rebelquarters, field of battle; this, combined with the production's consistent use of the hillside aisles among and alongside the audience, made the outdoor setting and we the audience wonderfully central to the play's action and significance. 
Music also played a vital role in this production of Henry IV, Part I. Before the play began, background music transitioned slowly from light, classical airs to distinctly martial tunes to a harder-driving rock-and-roll, in retrospect a sequence intended to telegraph the different arenas and contests the production would emphasize in its staging of Prince Hal's (Conner Neddersen) emergence and shifting understanding of his identity and responsibilities as prince. Music was used energetically to portray the Eastcheap world and Hal's cronies Sir John Falstaff (Tim Hyland), Bardolph (Brandon Felker), and Poins (Matthew Gilbert), with 1970s and 8os punk-rock music representing the eruptive and disruptive nature of this place and these people. Act I, scene I's opening action of the king at court was literally broken apart by the Eastcheap world, with The Damned's "Problem Child" suddenly interrupting and the stage's four panels rotating to become tavern-walls plastered with flyers advertising The Pogues. In the midst of King Henry's (David Anthony Lewis) rueful reflections on his "young Harry" versus Hotspur (Joe Ngo), Hal and his dubious companions came roaring in and with no spoken dialogue expressed the disorder the king perceives and fears in his son. Classic punk from the 70 s and 8's continued as the touchstone for Hal and Falstaff, to both witty and provocative effect: Falstaff enters Mistress Quickly's tavern at the opening of the act 3 'playing' scene to the tune of The Ramones' "I Wanna Be Sedated," and in act 1, the shift from scene one into the substance and dialogue of scene 2 is accompanied by The Clash's "London Calling."

This choice to convey Hal and his Eastcheap world in terms of this popular and angry music was hugely appealing, and it became a useful shorthand for Hal's as well as Falstaff's and Poins' characters. Such a choice runs the risk of over-simplifying Falstaff and especially Hal, and I did feel that some nuances of Falstaff as a more serious choric figure and of Hal as much more than an ingénue were traded-on with this music's powerful effect and also with some cutting of the play-text. But Tim Hyland as Falstaff gave a tremendous, thoroughly comic performance of Falstaff that anchored the entire play. Moreover, his Falstaff combined with the youthfulness and relative inexperience of the debuting Connor Neddersen as Hal made the play's punkEastcheap a provocative solution and a lot of fun, maybe especially for an audience made up of many baby-boomers and their children and even grandchildren.

Music plays a significant role in the play-text of Henry IV, Part I, of course, and Wooden O built on this while infusing their play with its own style. One of the play's key moments of characterization of the brave but unsubtle Hotspur occurs when the Welshman Owen Glendower's daughter sings in Welsh to a gathered company of rebels, including Hotspur and her husband, Edmund Mortimer. This scene and its notably unscripted Welsh woman's song are sometimes cut from contemporary productions of the play, but Wooden O's highly musical production included this scene and its song, blending the scene's specifics with a surprisingly 
modern sensibility by having Lady Mortimer sing Katy Perry's 2013 pop-feminist anthem, "Roar," in Welsh. The transposing of a very recent, very popular song into the play once again resulted in the drawing of characters and relationships with quite broad strokes. But such musical flourishes were not simply reductive. Throughout, Wooden O's production of Henry IV, Part I used popular music creatively in order to invite their audience into this chronicle history play.

In this Henry IV, Part I, Hal fundamentally is wrestling with questions of responsibility and manhood. He is doubled, famously, by Hotspur (the wonderfully tempestuous Joe Ngo) on one side, who embodies the martial prowess and honor that others doubt Hal possesses. And while Falstaff traditionally represents another, debauched double for Hal, in Wooden O's production Poins, played hilariously as an Entourage-style rock star by the excellent Matthew Gilbert, is just as significant and seductive an alter-ego for Hal. In Wooden O's version Hal is not highly calculating, but rather is an uncertain young man trying to choose a role model. Connor Neddersen as Hal is convincing as this uncertain young man, his at times less than confident performance actually enhancing this Hal. One of Neddersen's and the production's best scenes is the 'playing' scene from Act III, where Hal's simultaneous instruction by and necessary rejection of Falstaff is poignant. Neddersen's Hal, uneven as he was, also created a superb and moving moment with Hal's defeat of Hotspur and subsuming of his honor at the end of the play. In the moment of Hal's slaying of Hotspur, Neddersen and Joe Ngo as Hotspur were locked in a combat embrace whose violence and intimacy were visibly shocking to the untried prince. And in his famous reply to Hotspur's dying words -- "For worms, brave Percy. Fare thee well, great heart. / Ill-weaved ambition, how much art thou shrunk! / When that this body did contain a spirit, A kingdom for it was too small a bound;/ but now two paces of the vilest earth Is room enough" (V.iv.85-91) -- Neddersen's Hal spoke wonderingly, as someone new to combat and to contemplating its results. It was a riveting use of this Hal's ingenuousness to convey his new role and new understanding.

Over twenty-two years, Wooden $\mathrm{O}$ has built a following by presenting free productions of Shakespeare's plays that appeal to as well as challenge their audiences. With 2015's Henry IV, Part I,director (and Wooden O founding artistic director) George Mount and his cast and crew have continued this tradition. In the free program available at the performance, details for lowor no-cost access to Seattle Shakespeare Company productions were listed under the heading, "The Door is Open to You." To me, this phrase perfectly captures the achievement of this production: its creative treatment of its outdoor space, playful and affecting use of music, and thoughtful work with casting opened-up this history play for a contemporary and broad audience. 